\title{
Management of Educational Financing in Higher Education
}

\author{
Amrizal $^{1 *}$, Bahrun $^{2}$, Yusrizal $^{3}$ \\ ${ }^{1}$ Master in Education Administration Program Syiah Kuala University, Banda Aceh, Indonesia \\ 2,3 Prodi Magister Administrasi Pendidikan Universitas Syiah Kuala, Banda Aceh, Indonesia
}

\section{A R T I CLE I N F O}

Article history:

Received June 14, 2021

Revised June 15, 2021

Accepted October 24, 2021

Available online November 25, 2021

Kata Kunci :

Pembiayaan Pendidikan;

Pengelolaan, Pendidikan Tinggi

Keywords:

Educational Financing;

Management, Higher Education

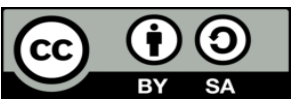

This is an open access article under the $\underline{C C}$ BY-SA license.

Copyright (C) 2021 by Author. Published by Universitas Pendidikan Ganesha

\begin{abstract}
A B S T R A K
Pendidikan merupakan salah satu investasi jangka panjang yang memiliki tujuan akhir untuk menghasilkan sumber daya manusia yang handal dan berdaya saing baik di tingkat lokal maupun global. Pembangunan pendidikan akan sulit tercapai jika tidak didukung oleh pendanaan yang memadai. Penelitian ini bertujuan untuk menganalisis perencanaan, pelaksanaan dan pengawasan biaya pendidikan dari $A P B N$ dan $A P B D$. Penelitian ini menggunakan metode deskriptif dengan pendekatan kualitatif. Teknik pengumpulan data berupa wawancara, observasi dan dokumentasi. Subyek penelitian ini adalah Kepala Biro Perencanaan dan Tata Usaha Sistem Informasi, Kepala Bagian Perencanaan, Kepala Bagian Keuangan, Kepala Tim Perencanaan dan Penganggaran Program/Sistem Penyusunan SP4, Kepala Bagian Informasi Bagian Sistem dan Kepala Badan Penjaminan Mutu. Hasil penelitian menunjukkan bahwa perencanaan menggunakan pola bottom up dengan SP4 dari unit kerja terendah hingga tingkat universitas, pelaksanaan anggaran digunakan untuk membiayai pengeluaran yang bersumber dari $A P B N$ dan $A P B D$. Pengendalian dilakukan sebagai pelaksanaan fungsi pengendalian dalam penyusunan Laporan Akuntabilitas Kinerja Instansi Pemerintah untuk menilai kinerja keuangan Badan Penjaminan Mutu atas pencapaian kinerja dari aspek kualitas. Sedangkan pengawasan dilakukan oleh BPKP, Bawasda dan Inspektorat Jenderal Kementerian Pendidikan Nasional. Pengelolaan pembiayaan merupakan evaluasi dalam peningkatan mutu pendidikan.
\end{abstract}

\section{A B S T R A C T}

Education is one of the long-term investments that has the ultimate goal of producing reliable, and competitive human resources at both the local and global levels. Educational development will be difficult to achieve if it is not supported by adequate funding. This study aims to analyze the planning, implementation and supervision of education costs from the APBN and APBD. This study uses a descriptive method with a qualitative approach. Data collection techniques in the form of interviews, observation and documentation. The subject of this research is the Head of the Planning and Information System Administration Bureau, the Head of the Planning Section, the Head of the Finance Section, the Head of the Program Planning and Budgeting/SP4 Preparation System Team, the Head of the Information System Section and the Head of the Quality Assurance Agency. The results of the study indicate that planning uses a bottom up pattern with SP4 from the lowest work unit to the university level, the implementation of the budget is used to finance expenditures sourced from the APBN and APBD. Control is carried out as the implementation of the controlling function in the preparation of the Performance Accountability Report for Government Agencies to assess financial performance, the Quality Assurance Agency for performance achievements from the quality aspect. Meanwhile, the supervision is carried out by the BPKP, Bawasda and the Inspectorate General of the Ministry of National Education. Financing management is an evaluation in improving the quality of education.

\section{INTRODUCTION}

Education is one of the long-term investments that has the ultimate goal of producing reliable, and competitive human resources at both the local and global levels (Sari \& Masruroh, 2018; Widiyono \& Irfana, 2021). The government has a big responsibility in improving education in the hope that it can produce generation with high quality and be able to bring the country towards positive change. The quality of human resources in question is not only mastering science and technology, but also having high adaptability towards changes and developments in life that are constantly occurring (Mustopa et al., 2021; Sudarso, 2017). Education is the main factor and essential strategy in improving the quality of human resources (Sonedi et al., 2017). Educational development changes in each year as an effort to keep up with developments. This educational change does not always become an existing educational problem-solving strategy, however, it often creates new problems that are much more complicated than the initial problem. Since, there is no limits on development of education, the education will always be an issue in a nation. 
Therefore, the education development agenda improves and follows up of the dynamics of society. Furthermore, education can be seen as the main factor for a nation to prepare a better future. Society nowadays desired extensive development, for instance vision, knowledge, educational processes, and values which have to develop for the purpose in facing challenges of the complex future.

For those reasons, it will be difficult to support the development of education if it is not supported by the provision of adequate funds (Abidin, 2017; Lubis, 2021). Cost is a very important component to support the efforts to organize and improve a quality education system, it can be said that the education process cannot run without financial support (Abidin, 2017). Therefore, the implementation of education financing must also be supported by a proper management, by empowering its functions which include Planning, Organizing, Implementation and Supervision (Usman, 2016). Indeed, proportional cost management is an obvious to reach higher quality and professional educational policies. Education financing is a cost that must be budgeting, include the calculation or costs that spend for all school activities that have relevance to education (Lubis, 2021; Winarsih, 2019). In financing management there are a series of activities including financing plans, implementation, supervision and report of financing (Kurniady et al., 2018). Financial management requires transparency to receive a trust from stakeholders. Previous research revealed that a good financing system can realize a good quality education as well (Kurniady et al., 2018; Masditou, 2017). Both of Management of educational financing and learning facilities on school has a strong influence on the quality of education (Azhari \& Kurniady, 2016). There are many previous research findings related to financing management, however it has never been carried out and studied in depth at Syiah Kuala University. This study aims to analyze financing management at Syiah Kuala University. The existence of this research is expected to be an evaluation of financing management at Syiah Kuala University and in hope that it can improve the quality of education.

\section{METHODS}

The research method used in descriptive research is a qualitative approach. Descriptive research is intended to provide a clearer descriptive of social situations by focusing on certain aspects and often showing the relationship between several variables. This research was conducted at the Administrative Headquarters of Syiah Kuala University, which is in the work units relevant to the management of education financing, namely the Planning and Information Systems Administration office and the General Administration and Finance office. The subjects in this study were the Head of the Administration and Information Systems office, the Head of the Program Planning and Budgeting/SP4 Preparation System Team, the Head of the Planning Section, the Head of the Finance Section, the Head of the Information System Section, the Quality Assurance Agency. Methods of data collection using observation, interviews and documentation analysis. The research instrument used in this study was a sheet equipped with interview guidelines and target questions. The analysis technique is carried out in three steps, includes data reduction, display and verification.

\section{RESULT AND DISCUSSION}

\section{Results}

Based on the results of the analysis obtained information that the management of financing at Syiah Kuala University through three stages, namely, planning, implementation and control. The planning process in the context of program preparation and development at Syiah Kuala University begins with performance evaluation activities. Syiah Kuala University as part of the higher education system implements the SP4 system in its planning and budgeting process, while in its implementation using a bottom-up system. The determination of the priority scale is based on an analysis of needs that are considered urgent. Based on standard operating procedures for planning and budgeting, the preparation of education financing plans is implemented in the activities of preparing the work plan of Syiah Kuala University. The preparation of a financing plan for Syiah Kuala University includes activities 1). Meetings of the Faculty / Rectorate / Institutions. 2) Performance Evaluation Coordination Meeting of Syiah Kuala University. 3) National Working Education Development Direction and Policy Meeting. 4). Preparation of Work Plans. 5) Drafting of the Activity Program Plan and Budget of Syiah Kuala University Syiah Kuala University. 6). Coordination, Synchronization, and Consolidation of Draft Plans, Programs, Activities and Budgets of Syiah Kuala University with the Planning office of the Ministry of National Education. 7) Development Planning Consultation (Musrenbang). 8). Adjustment of the Draft Program and Activity Plan of Syiah Kuala University with the Directorate General of Higher Education, Ministry of National Education.

In addition, the preparation of program plans, activities and financing of Syiah Kuala University refers to strategic issues in the education sector, as well as making an analysis of the external and internal 
environment contained in the SWOT analysis, including an analysis that contains strengths, weaknesses, opportunities and threats. Through analyzing the weaknesses, it can be seen which components are considered as inhibiting factors for improving performance. It needs a performance improvement strategy to cover these weaknesses. The SWOT analysis of Syiah Kuala University for input material for the 2020 work plan is as shown in Table 1.

Table 1. Analysis Weaknesses, Strengths, Opportunities and Challenges in the Work Plan Syiah Kuala University

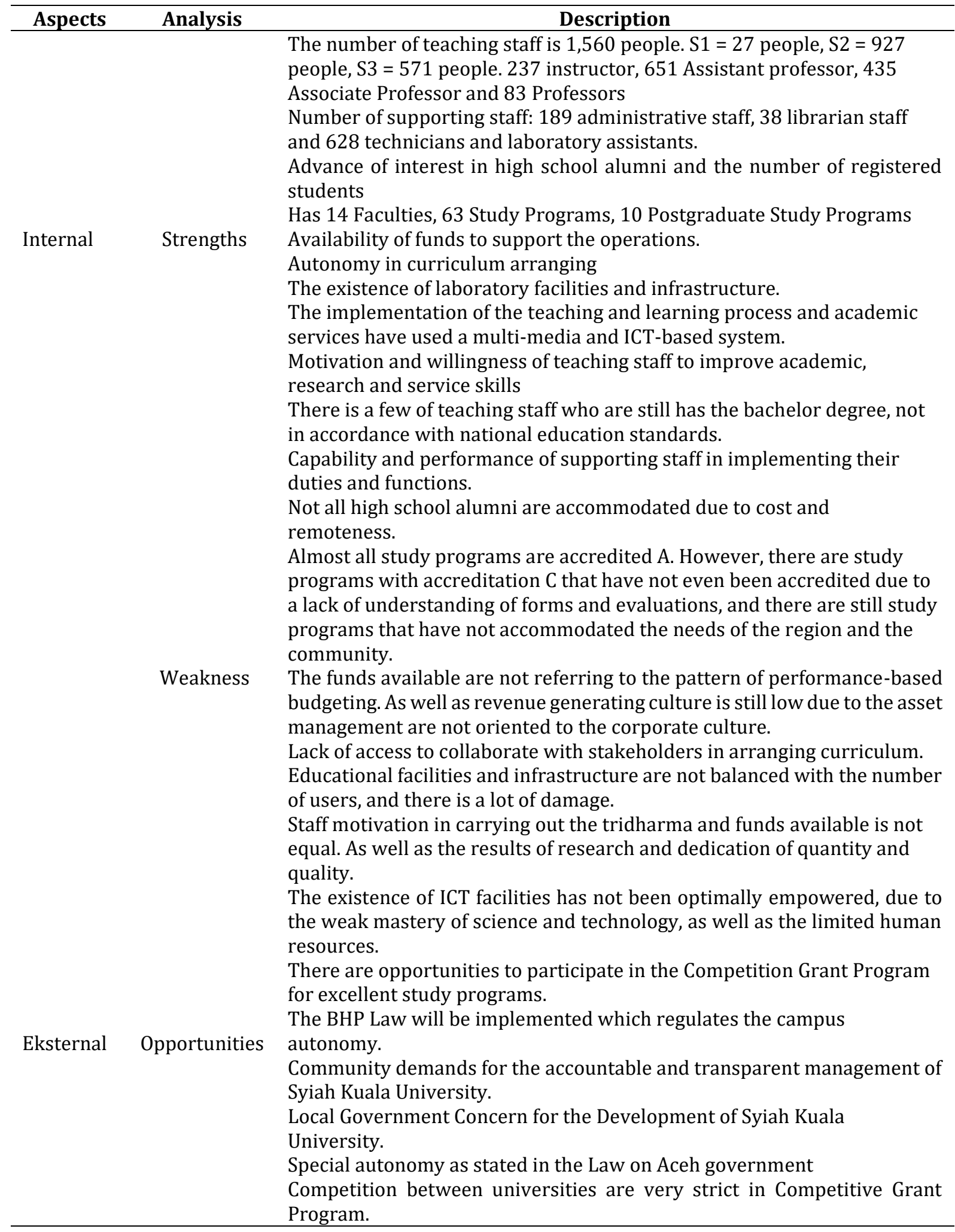




\begin{tabular}{ccl}
\hline Aspects & Analysis & \multicolumn{1}{c}{ Description } \\
\hline Threat & Not all elements accept and understand the pattern of university \\
& management with BHP. \\
& The laws and regulations on transparency and accountability have not \\
& been well socialized by related parties. \\
& There is no proper targeting in the use of higher education funds. \\
\hline
\end{tabular}

The result of the work meeting of Syiah Kuala University is a matrix that describes plans, programs and activities for the next fiscal year that are aligned with the policy direction of the Strategic Plan of the Ministry of National Education. The analysis shows that the proposals for faculties and work units within Syiah Kuala University are relatively large, and it is exceeding the budget plan that has been set. As a result, not all activities proposed by the faculties and work units are accommodated for follow-up in the preparation of program plans and budgets for Syiah Kuala University. Syiah Kuala University SP4 team whose members are representatives from faculties makes accurate decisions, activities that are made as top priorities to be used as material for proposals in program plans, activities and budgets of Syiah Kuala University. The stage of implementing education financing for the 2020 fiscal year at Syiah Kuala University. on the implementation education financing, Standard Operating Procedure is applied in the preparation of budgeting activities until the release of the Budget Implementation List (DIPA) for the State Budget and the Budget Implementation Document for the Local Government Budget. All of these documents are contained in the various programs, activities and budgets contained in the proposal. In the budget plan, the revenues and expenditures of Syiah Kuala University are broadly grouped into two activities, which are revenues and expenditures. Based on the results of interviews, the financial acceptance procedure of Syiah Kuala University set by the Syiah Kuala University government does not deviate from the guidelines for use and expenditure, Syiah Kuala University is only the implementer of budget users at the micro-institutional level. The source of education financing at Syiah Kuala University is the State Budget (APBN), in the document it is divided into 3 (three) sources, namely ex-routine and ex-development expenditure which is called Pure National Budget (RM) and state non-tax revenue (PNBP) funds obtained from tuition and other education income from Syiah Kuala University.

The mechanism for implementing and using the budget for various activities at Syiah Kuala University refers to the Presidential Decree of the Republic of Indonesia Number 80 of 2003 in conjunction with Presidential Regulation no. 8 of 2006 concerning Guidelines for the Implementation of Government Procurement of Goods and Services. The funding for education at Syiah Kuala University from the APBN is Rp. 664,315.629,000, - . When calculated based on unit costs, the number of students enrolled at Syiah Kuala University in the Academic Year of 2020 is 21,345 people, then the unit cost of Syiah Kuala University is Rp. $9,769,782,-/$ student. The unit cost does not meet the ideal standards that have been set. Because the ideal standard for higher education unit costs is Rp. 18,000,000, -/student. The problem of small unit costs is an obstacle for most universities, especially those that do not have the status of a State-Owned Legal Entity. The small unit cost greatly affects the quality of learning and educational services. This is also not in accordance with what is mandated in the National Education Standards, Government Regulation Number 60 of 1999 concerning Higher Education, and Law Number 8 of 2009 concerning Educational Legal Entities. These laws and regulations recommend that universities increase revenue to the maximum in order to strengthen independence, autonomy without compromising quality.

Financing planning is not only formulated about the amount of the budget, it is also formulated about the targets to be achieved. Supervision is needed to avoid deviation in achieving targets and performance goals. According the results of interviews, the control is carried out by the internal party of Syiah Kuala University, while the supervision involves external parties, both from the Inspector General of the Ministry of National Education, Finance and Development Supervisory Agency and from Bawasda. Supervision is required to produce information about the implementation of various operational activities that are currently taking place. The information was obtained in various ways such as by reporting, interview results, distribution, questionnaires and direct observation by supervisors in the field. Observations are carried out by monitoring activities that are being and have been done. Monitoring does not only receive reports from implementing activities, but also analyzes the suitability of activities and plans, both from physical and non-physical aspects in the field. For instance, monitoring the conformity of the specifications of goods, tools or other physical things between the accountability reports and stuff before they are given to consumers by the procurement committee and the recipient of stuff. According to the results of the interview, the control system refers to the standard, Report on Accountability and Performance of Government Institutions is prepared based on the applicable laws and regulations, while the Quality Assurance Agency is based on the internal quality audit manual as a guideline for monitoring and evaluating performance. The control system is carried out by the Quality Assurance Agency of Syiah 
Kuala University periodically. It is required to avoid deviations from the predetermined plan. If deviations goes far then it will be difficult to control. Furthermore, regarding the financing of the management, control also aimed to evaluate the stages use state finances, which starts from the planning process to the control process.

\section{Discussion}

Evaluation of education financing management at Syiah Kuala University can compare the standards that have been determined with the implementation carried out. Thus, if there is the difference between the existing of minimum cost standard rules and the implementation, it will be seen evidently in the implementation of education financing management at Syiah Kuala University. Planning for education financing at Syiah Kuala University adheres to a comprehensive education planning pattern, the overall concept is arranged systemically and systematically. Systemic means that it is to plan or to set the objectives, develop programs, find costs alternatives, and use a budgeting process that reflects long-term program activities (Ekowati et al., 2020). Accurate data and information that can be granted are formulated into a priority scale on education financing planning. Planning for education financing will be faced with various forces and interests that will affect the formulation process. Therefore, the requirements in planning are able to identify various strengths, weaknesses, opportunities and challenges (SWOT) that will be able to influence the planning process.

The educational process, including educational administration services, is carried out in accordance with SOP. The budgeting approach with a medium-term perspective provides a comprehensive framework, improves the linkage of planning and budgeting processes, develops fiscal discipline, directs resource allocation to be more rational and strategic, and increases public confidence in government activities by providing optimal and more efficient services. Integrated budgeting is carried out by integrating all planning and budgeting as a unified whole, collecting all activities originating from the routine budget, development budget and non-tax state revenues (PNBP) into one planning document, called DIPA or DPA (Sutrisno, 2018). Syiah Kuala University implemented DIPA and DPA based on the RKA-KL and RKA-SKPD which resulted in a change in the management of education costs with the abolition of the project. Cost management orientation is program oriented, not project oriented. it is determined who is in charge of each program and activity In order to the implementation of the budget run in an orderly, smooth, efficient, transparent and accountable manner. (Lengkong et al., 2019; Nurlaeli, 2020).

Basically, budgeting is a negotiation or agreement between the top leadership and other leaders in determining the amount of budget allocation (Masditou, 2017). The function of the budget is a tool both for planning and controlling, as well as for management in directing Management is not an easy thing to do, especially when it comes to finances or costs. In financial management, accuracy is required in managing finances (Murniati \& Usman, 2015). The quality assurance system in realizing the quality of education at universities has been running well and has implications for improving the quality of education services. Furthermore, the strategy used has referred to 4 stages, which are: Standard Setting, Standard Compliance, Continuous Evaluation, and Quality Improvement. Good financing management can be seen from good financing planning, implementation and control (Margareta \& Ismanto, 2017; Prasetio, 2016). The findings of this study support other research which states that financing management affects the quality of education in elementary schools (Masditou, 2017; Usman, 2016). With a good education financing management system, it will be able to support, and also guarantee the development of education quality and the process of organizing teaching and learning activities. From the discussion above, it can be derived that financial management is one of the determining factors and drivers of programs in institutions, including Syiah Kuala University. The findings indicate that the implementation of financing with indicators of conformity between planning and implementation is carried out in a good way. It is appeared from leader's effort to achieve the educational goals based on budget plan and rules by the government. Additionally, this study can be used as an evaluation in planning for the further financing management, in the hope that process of improving educational quality can be optimal.

\section{CONCLUSION}

From the findings and explanation above, it can be derived that the planning process in education financing management at Syiah Kuala University adopt a bottom-up pattern. In addition, the implementation of education financing at Syiah Kuala University is implemented in the arranging and spending of the budget. Control is also carried out to avoid deviations activities which has been planned both from the annual and the Strategic Plan. However, this study has limitations, it was only conducted at one university. Further research have to add research subjects in order to obtain more accurate 
information. Nevertheless, the implications of this research are expected to improve financing management in educational institutions.

\section{REFERENCES}

Abidin, A. A. (2017). Manajemen pembiayaan pendidikan tinggi dalam upaya peningkatan mutu (Studi kasus pada perguruan tinggi swasta menengah di Surabaya). Jurnal Penjaminan Mutu, 3(1), 87-99. https://doi.org//10.25078/jpm.v3i1.95.

Azhari, U. L., \& Kurniady, D. A. (2016). Manajemen Pembiayaan Pendidikan, Fasilitas Pembelajaran, Dan Mutu Sekolah. Jurnal Administrasi Pendidikan, 23(2). https://doi.org/10.17509/jap.v23i2.5631.

Ekowati, T. E., Sunandar, S., \& Murniati, N. A. N. (2020). Manajemen Pembiayaan Pendidikan Di Sekolah Dasar Islam Ar Rahmahkecamatan Suruh. Jurnal Manajemen Pendidikan (JMP), 9(1), 1-21. https://doi.org/10.26877/jmp.v9i1.6836.

Kurniady, D. A., Setiawati, L., \& Nurlatifah, S. (2018). Manajemen Pembiayaan Pendidikan Terhadap Mutu Sekolah Menengah Kejuruan. Jurnal Penelitian Pendidikan, 17(3), 263-269. https://doi.org/10.17509/jpp.v17i3.9620.

Lengkong, S. M. K., Rotinsulu, D. C., \& Walewangko, E. N. (2019). Pengaruh Alokasi Anggaran Pendidikan Dan Kesehatan Terhadap Indeks Pembangunan Manusia Dan Dampaknya Terhadap Pertumbuhan Ekonomi Kota Bitung. Jurnal Pembangunan Ekonomi Dan Keuangan Daerah, 19(2), 1-20. https://doi.org/10.35794/jpekd.15783.19.2.2017.

Lubis, R. R. (2021). Manajemen Pembiayaan Pendidikan dalam Meningkatkan Mutu Pendidikan di Madrasah Aliyah Imam Muslim Serdang Bedagai. Jurnal Agama Dan Pendidikan Islam, 13(1), 119134. https://doi.org/10.30596\%2Fintiqad.v13i1.6244.

Margareta, R., \& Ismanto, B. (2017). Strategi Perencanaan Pembiayaan Sekolah dalam Peningkatan Mutu di SMP Negeri. Jurnal Manajemen Pendidikan, 4(2), 195-204. https://doi.org/10.24246/j.jk.2017.v4.i2.p195-204.

Masditou. (2017). Manajeman Pembiayaan Pendidikan Menuju Pendidikan yang Bermutu. Jurnal ANSIRU PAI, 1(2), 119-145. https://doi.org/10.30821/ansiru.v1i2.1518.

Murniati, AR, \& Usman, N. (2015). Manajemen Pembiayaan pendidikan dalam Meningkatkan Mutu Pembelajaran pada MTsN Janarata Kecamatan Bandar Kabupaten Bener Meriah. Jurnal Administrasi Pendidikan: Program Pascasarjana Unsyiah, 3(4), 123-129. http://202.4.186.66/JAP/article/view/2598.

Mustopa, R., Barjah, M. K., Ahsaina, N. A., \& Rais, Y. (2021). Pelatihan dan Pengembangan Manajemen Sumber Daya Manusia di Masa Pandemi Covid-19. Jurnal Sosial Dan Teknologi, 1(3), 166-174. https://doi.org/10.36418/jurnalsostech.v1i3.21.

Nurlaeli, A. (2020). Perencanaan Pembiayaan Berbasis Planning Programming Budgetting System (PPBS) di Sekolah Dasar Islam Terpadu Anni'mah Bandung. Jurnal Islamic Education Management, 5(1), 29-40. https://doi.org/10.15575/isema.v5i1.8912.

Prasetio, A. (2016). Manajemn Pemasaran,Analisis Perencanaan dan Pengendalian. Management Analysis Journal, 1(4).

Sari, M., \& Masruroh, F. (2018). Pengaruh Motivasi Dan Disiplin Kerja Terhadap Kinerja Pegawai Di Kecamatan Magelang Tengah Kota Magelang. Jurnal Mahasiswa Administrasi Negara (JMAN), 02(02), 36-51.

Sonedi, S., Jamalie, Z., \& Majeri, M. (2017). Manajemen Pembiayaan Pendidikan Bersumber dari Masyarakat. Fenomena, 9(1), 25. https://doi.org/10.21093/fj.v9i1.702.

Sudarso, A. P. (2017). Analisis Pengaruh Gaya Kepemimpinan Dan Insentif Terhadap Kinerja Karyawan Pada Yayasan Pendidikan Mulia Buana. JENIUS (Jurnal Ilmiah Manajemen Sumber Daya Manusia), 1(1). https://doi.org/10.32493/jjsdm.v1i1.659.

Sutrisno. (2018). Analisis Faktor-Faktor Yang Mempengaruhi Efektivitas Perencanaan Dan Penganggaran. REVITALISASI : Jurnal Ilmu Manajemen, $107-111$. https://doi.org/10.32503/revitalisasi.v7i1.789.

Usman, J. (2016). Urgensi Manajemen Pembiayaan Dalam Peningkatan Mutu Pendidikan Madrasah. TADRIS: Jurnal Pendidikan Islam, 11(2), 219. https://doi.org/10.19105/tadris.v11i2.1170.

Widiyono, A., \& Irfana, S. (2021). Implementasi Merdeka Belajar melalui Kampus Mengajar Perintis di Sekolah Dasar. Metodik Didaktik: Jurnal Pendidikan Ke-SD-An, 16(2), 102-107. https://doi.org/10.17509/md.v16i2.30125.

Winarsih, sri. (2019). Kebijakan dan Implementasi Manajemen Pembiayaan dalam Meningkatkan Mutu Pendidikan di Sekolah. International Conference of Moslem Society, 1, 124-135. https://doi.org/10.24090/icms.2016.2409. 